University of Nebraska - Lincoln

DigitalCommons@University of Nebraska - Lincoln

\title{
Apoplastic redox metabolism: Synergistic phenolic oxidation and a novel oxidative burst
}

C. Jacyn Baker

USDA, jacyn.baker@ars.usda.gov

Daniel P. Roberts

USDA, dan.roberts@ars.usda.gov

Norton M. Mock

USDA

Bruce D. Whitaker

USDA

Kenneth L. Deahl

USDA

See next page for additional authors

Follow this and additional works at: https://digitalcommons.unl.edu/usdaarsfacpub

Part of the Agricultural Science Commons

Baker, C. Jacyn; Roberts, Daniel P.; Mock, Norton M.; Whitaker, Bruce D.; Deahl, Kenneth L.; and Aver'yanov, Andrey A., "Apoplastic redox metabolism: Synergistic phenolic oxidation and a novel oxidative burst" (2005). Publications from USDA-ARS / UNL Faculty. 337.

https://digitalcommons.unl.edu/usdaarsfacpub/337

This Article is brought to you for free and open access by the U.S. Department of Agriculture: Agricultural Research Service, Lincoln, Nebraska at DigitalCommons@University of Nebraska - Lincoln. It has been accepted for inclusion in Publications from USDA-ARS / UNL Faculty by an authorized administrator of DigitalCommons@University of Nebraska - Lincoln. 


\section{Authors}

C. Jacyn Baker, Daniel P. Roberts, Norton M. Mock, Bruce D. Whitaker, Kenneth L. Deahl, and Andrey A. Aver'yanov 


\title{
Apoplastic redox metabolism: Synergistic phenolic oxidation and a novel oxidative burst ${ }^{\text {th }}$
}

\author{
C. Jacyn Baker ${ }^{\mathrm{a}, *}$, Daniel P. Roberts ${ }^{\mathrm{b}}$, Norton M. Mock ${ }^{\mathrm{a}}$, Bruce D. Whitaker ${ }^{\mathrm{c}}$, \\ Kenneth L. Deahl' ${ }^{\mathrm{d}}$, Andrey A. Aver'yanov \\ ${ }^{a}$ Molecular Plant Pathology Laboratory, Bldg. 004 Rm. 119, USDA, Beltsville, MA 20705, USA \\ ${ }^{\mathrm{b}}$ Sustainable Agricultural Systems Laboratory, USDA, Beltsville, MA 20705, USA \\ ${ }^{\mathrm{c}}$ Produce Quality and Safety Laboratory, USDA, Beltsville, MA 20705, USA \\ ${ }^{\mathrm{d}}$ Vegetable Laboratory, USDA, Beltsville, MA 20705, USA \\ ${ }^{\mathrm{e}}$ Research Institute of Phytopathology, B. Vyazemy, Moscow Region 143050, Russia
}

Accepted 24 April 2006

\begin{abstract}
The plant apoplast is an important mediator of communication between the cell cytoplasm and its surroundings. Plant cell suspensions offer a convenient model system to gain insight into apoplastic physiology. Here, we describe a novel phenomenon that took place when two naturally occurring phenolics were added together to either soybean or tobacco cell suspensions. Acetosyringone (AS) and/or hydroxyacetophenone (HAP), phenolics found in the extracellular/apoplast of tobacco cells, were added to soybean or tobacco cell suspensions undergoing an oxidative burst. Individually, AS appeared to be utilized as a typical peroxidase substrate to scavenge hydrogen peroxide, while HAP was utilized at a much lower rate. However, when added together the rate of utilization of both phenolics increased and surprisingly resulted in the production of hydrogen peroxide. We have further characterized this novel phenomenon in suspension cells. This study demonstrates that certain phenolics in plants can cause co-oxidation which, as in animals, could alter the structure and bioactivity of surrounding phenolics.
\end{abstract}

Published by Elsevier Ltd.

Keywords: Co-oxidation; Phenolics; Glycine max; Nicotiana tabacum; Pseudomonas syringae; Oxidative burst; Hydrogen peroxide; Apoplast; Redox metabolism; Suspension cells

\section{Introduction}

The apoplast matrix that surrounds the plant cell is a complex and dynamic micro-environment. When outside stresses, such as environmental changes or pathogen attack occur, the micro-environment of the apoplast is likely to be the first line of defense. The cross-linked cell wall polysaccharides provide a backbone to the matrix within

\footnotetext{
Abrreviations: AS, acetosyringone; HAP, 4-hydroxyacetophenone; ROS, reactive oxygen species; HKbac, heat-killed bacteria

${ }_{2}$ Mention of a trade name, proprietary product, or vendor does not constitute a guarantee of the product by the United States Department of Agriculture and does not imply its approval to the exclusion of other vendors that may also be suitable.

${ }^{*}$ Corresponding author. Tel.: + 1301504 5617; fax: + 13015045449 .

E-mail address: bakerc@ba.ars.usda.gov (C. Jacyn Baker).
}

which various proteins, enzymes, metabolites, and inorganic ions are associated. Localized responses to bacterial or fungal attacks often result in structural alterations, such as lignification and papillae formation, involving multiple matrix components including callose, phenolics, and hydroxyproline-rich proteins [1,2], or physiological alterations of the apoplast environment, such as increased $\mathrm{pH}$ or production of reactive oxygen species.

Due to the complexity and inaccessibility of the apoplast, examining its rapidly changing stress-related chemistry in vivo remains a challenge. However, analysis of the extracellular/apoplast chemistry of cell suspensions, which mimic stress-related symptoms observed in planta, can provide insight. In our studies of extracellular phenolics during plant/bacterial interactions in suspension cells, we found that qualitative and quantitative changes in 
phenolic composition were dependent on several factors with the predominant factor being the type of bacteria present $[3,4]$. When suspension cells were treated with a pathogen that caused an incompatible response and oxidative burst, the concentration of the extracellular phenolics decreased or disappeared as a result of oxidation. We also found that an extracellular phenolic produced by tobacco cells, AS, had a bioactive effect that accelerated the plant/bacterial interaction when added exogenously [5].

In this report, we demonstrate a novel phenomenon that brought new insight to our understanding of apoplastic redox metabolism. In an attempt to protect apoplastic phenolics in soybean suspensions from oxidation prior to their analysis, we added two commercially available plant phenolics, AS and HAP, to serve as antioxidants. Surprisingly, we discovered that the relatively high concentrations of these exogenous phenolics were (1) rapidly oxidized and (2) resulted in a large oxidative burst. We demonstrate that certain phenolics trigger a unique chemistry in the extracellular/apoplast environment of suspension cells that results in a prooxidant environment rather than an antioxidant environment as expected. In addition, we demonstrate that phenolic co-oxidation can occur in the extracellular/apoplast environment of suspension cells. Phenolic co-oxidation is currently an area of intense study and concern in the pharmaceutical industry $[6,7]$ where the co-administration of certain phenolic drugs can cause modification of their structure and bioactivity.

The same principle of phenolic co-oxidation in animals could occur in the plant apoplast, where the introduction of certain phenolics, whether from the cell cytoplasm or invading micro-organisms, could lead to structural and bioactive modification of pre-existing apoplast phenolics. Because this could be insightful for understanding the complexity of apoplastic redox metabolism, we decided to investigate and characterize this phenomenon in suspension cells. The chemical mechanisms involved are also currently being investigated.

\section{Materials and methods}

\subsection{Chemicals}

Horseradish peroxidase (P-8250), soybean peroxidase (P-1432), AS (3,5-dimethoxy-4-HAP, D134406), 4-HAP (278564), and all suspension culture ingredients were purchased from Sigma-Aldrich Chemicals Inc., St. Louis, MO, USA. The peroxidases were purchased and measured in units as described by Sigma; one unit (U) will oxidize $1 \mu$ mole of 2,2'-azino-bis (3-ethylbenzthiazoline-6-sulfonic acid) $\min ^{-1}$.

\subsection{Plant material}

Soybean (Glycine max L. Merr. cv Harosoy) suspension cells were originally isolated from hypocotyl callus and maintained in Gamborg's B-5 medium (Gibco, Grand
Island, NY, USA) augmented with $1 \mathrm{mg} \mathrm{L}^{-1}$ 2,4-D, $\mathrm{pH} 5.0$. Suspension cultures of tobacco (Nicotiana tabacum L. cultivar Hicks) were derived from pith and maintained on MS media, supplemented with $0.2 \mathrm{mg} \mathrm{L}^{-1} \quad \mathrm{KH}_{2} \mathrm{PO}_{4}$, $0.2 \mathrm{mg} \mathrm{L}^{-1}$ 2,4-D and $0.1 \mathrm{mg} \mathrm{L}^{-1}$ kinetin, $\mathrm{pH}$ 5.8. Soybean and tobacco cultures were routinely transferred, 10 into $80 \mathrm{~mL}$ of fresh media in $250 \mathrm{~mL}$ flasks, every 4 days and incubated on a rotary shaker at $150 \mathrm{rpm}$ and $27^{\circ} \mathrm{C}$ in the dark.

Suspension cells were washed and suspended in assay buffer, containing $0.5 \mathrm{mM} \mathrm{CaCl}_{2}, 0.5 \mathrm{mM} \mathrm{K}_{2} \mathrm{SO}_{4}, 175 \mathrm{mM}$ mannitol and $0.5 \mathrm{mM}$ MES, $\mathrm{pH}$. Then $25 \mathrm{~mL}$ of the cell suspensions, $0.05 \mathrm{~g} \mathrm{~mL}^{-1}$, were dispensed into $50 \mathrm{~mL}$ beakers on a rotary water bath shaker set at $27^{\circ} \mathrm{C}$ and $180 \mathrm{rpm}$ to keep cells suspended. Stock solutions, $20 \mathrm{mM}$, of AS and HAP, were made in assay buffer and were added directly to the cell suspensions using less than $125 \mathrm{uL}$ per beaker to produce final phenolic concentrations ranging up to $100 \mu \mathrm{M}$. All experiments were preformed at least twice with two or more replicates per treatment.

\subsection{Heat-killed bacteria (HKBac) preparation}

Cultures of Pseudomonas syringae pv. syringae 61, isolate WT, were grown for $20 \mathrm{~h}$ in Kings B broth, centrifuged, washed, and suspended in deionized water. Based on optical density, the concentration of the suspension was adjusted with water so that addition of about $200 \mu \mathrm{L}$ of the bacterial suspension to plant cell suspensions resulted in the desired final concentration of about $10^{8} \mathrm{cfu} \mathrm{mL}^{-1}$. The bacterial suspensions were then autoclaved for $15 \mathrm{~min}$ and frozen until used.

\subsection{HPLC-UV quantification of phenolics}

One-milliliter samples of cell suspensions were filtered through Miracloth and centrifuged at $12,000 \mathrm{~g}$ for $5 \mathrm{~min}$ prior to HPLC analysis. AS and HAP were separated and quantified using a Onyx monolith C18 analytical column, $100 \times 4.6 \mathrm{~mm}$ i.d., (Phenomenex, Torrence, CA, USA) with a Waters (Milford, MA) quaternary pump, autosampler, photodiode array detector, and Empower data acquisition on a Dell Pentium 4 computer. Aliquots, $150 \mu \mathrm{L}$, of samples were acidified with phosphoric acid $(0.1 \%)$ and placed in the autosampler using a $10 \mu \mathrm{L}$ injection volume. An isocratic mobile phase of $30 \%$ methanol in $0.01 \%$ aqueous phosphoric acid, $2 \mathrm{~mL} \mathrm{~min}^{-1}$, separated the phenolics within $4 \mathrm{~min}$. Quantification using peak height was preformed using the UVmax wavelength for each peak, AS, $300 \mathrm{~nm}, \mathrm{HAP}, 276 \mathrm{~nm}$, and calibration with standards.

\subsection{FOX2 (ferrous oxidation in xylenol orange) assay for hydrogen peroxide}

In this spectrophotometric method, ferrous ions are oxidized by hydrogen peroxide to ferric ions, which bind 
with xylenol orange to give a colored complex with increased absorbance at $560 \mathrm{~nm}$ [8]. The advantage of this technique is that it does not rely on peroxidase which is affected by the exogenous phenolics added during this study. The FOX2 reagent contains $125 \mu \mathrm{M}$ xylenol orange, $250 \mu \mathrm{M}$ ammonium ferrous sulfate, $4 \mathrm{mM}$ butylated hydroxytoluene in $90 \%$ methanol containing $25 \mathrm{mM}$ sulfuric acid. Using a 96-well plate, $270 \mathrm{uL}$ of FOX2 reagent was added to $30 \mathrm{uL}$ samples that had been filtered through Miracloth to remove cells. After 30 min incubation, the plates were read at $560 \mathrm{~nm}$ using a Molecular Devices Versamax micro-plate reader (Sunnyvale, CA, USA). The absorbance change was compared to hydrogen peroxide standards.

\section{Results}

\subsection{Metabolism of exogenous $A S$ and HAP by suspension cells}

AS and HAP, $100 \mu \mathrm{M}$, were added to soybean suspension cells either separately or in combination (Fig. 1). The concentrations of each of the phenolics were monitored periodically by HPLC-UV. The concentration of $\mathrm{H}_{2} \mathrm{O}_{2}$ in the supernatant was measured using a peroxidase-independent spectrophotometric assay (FOX2). Untreated soybean cells, $0.05 \mathrm{~g} \mathrm{~mL}^{-1}$, produced a small initial burst of $\mathrm{H}_{2} \mathrm{O}_{2}$, nearly $20 \mu \mathrm{M}$, due to the physical transfer of cells to assay buffer (Fig. 1A). This initial accumulation of $\mathrm{H}_{2} \mathrm{O}_{2}$ was not observed in soybean cells treated with exogenous AS, $100 \mu \mathrm{M}$, which is consistent with phenolics serving as peroxidase substrates during the scavenging of $\mathrm{H}_{2} \mathrm{O}_{2}$. This is supported by HPLC-UV analysis (Fig. 1B), which indicated that the extracellular AS concentration in these suspensions decreased about $30 \mu \mathrm{M}$ during the first $2 \mathrm{~h}$ of the monitoring period. Soybean cells treated with $100 \mu \mathrm{M}$ HAP produced a burst of hydrogen peroxide similar to untreated cells, suggesting that under these conditions HAP was not as good a substrate for apoplastic peroxidases to efficiently scavenge $\mathrm{H}_{2} \mathrm{O}_{2}$ (Fig. 1A). The concentration of HAP in these suspensions decreased about $7 \mu \mathrm{M}$ over this monitoring period (Fig. 1B).

Surprisingly, when soybean suspensions were treated with both phenolics, $100 \mu \mathrm{M}$ each, a greater production of $\mathrm{H}_{2} \mathrm{O}_{2}$ occurred reaching concentrations of $80-90 \mu \mathrm{M}$ (Fig. 1A). In addition, the loss of both phenolics was greater than when these compounds were added individually, depleting nearly all of the AS within $3 \mathrm{~h}$, and reducing the $\mathrm{HAP}$ to $50 \mu \mathrm{M}$. Despite the continued presence of $\mathrm{H}_{2} \mathrm{O}_{2}$, the loss in HAP appeared to nearly stop after $3 \mathrm{~h}$ when the AS was nearly depleted.

\subsection{Metabolism of AS and HAP by peroxidases}

To determine whether extracellular peroxidases may be involved in this phenomenon, we carried out similar experiments in vitro with similar activities of horseradish
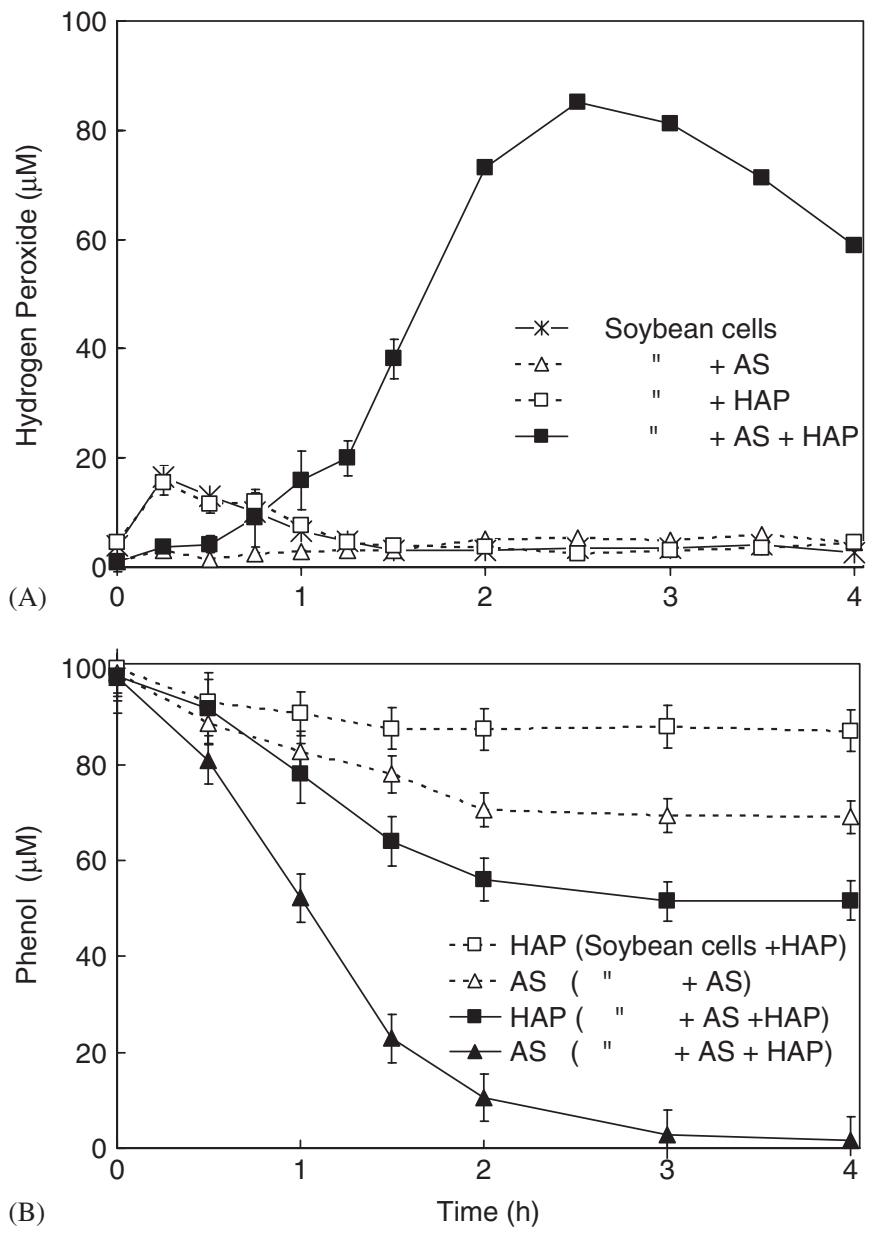

Fig. 1. Monitoring the extracellular $\mathrm{H}_{2} \mathrm{O}_{2}$ levels and phenolic concentrations of suspensions of soybean cells treated with acetosyringone (AS) and hydroxyacetophenone (HAP). The suspensions contained cells, $0.5 \mathrm{~g} \mathrm{~mL}^{-1}$ and either $100 \mu \mathrm{M}$ AS or HAP, or both AS and HAP. Samples were periodically removed. (A) Hydrogen peroxide was measured spectrophotometrically@560nm using the FOX2 assay which involved oxidation of xylenol orange. (B) The concentration of the exogenously added phenolics, AS and HAP, was quantified using HPLC-UV. See Section 2 for details.

peroxidase and soybean peroxidase in $25 \mathrm{~mL}$ of assay buffer. The phenolics, $50 \mu \mathrm{M}$, were added separately or in combination with exogenous $\mathrm{H}_{2} \mathrm{O}_{2}, 100 \mu \mathrm{M}$. The findings were similar for both, but only the horseradish peroxidase results are shown (Fig. 2). Using peroxidase activities similar to the soybean suspension cells, AS alone was a much better substrate than HAP alone, based on the utilization of $\mathrm{H}_{2} \mathrm{O}_{2}$ (Fig. 2A) and phenolic degradation (Fig. 2B); AS was reduced nearly $70 \%$ over the $3 \mathrm{~h}$ monitoring period while HAP was reduced less than $5 \%$.

As with the soybean suspension cells, the in vitro degradation of both phenolics was increased when they were present together; more than $90 \%$ of the AS was degraded and about $50 \%$ of the HAP (Fig. 2B). The utilization of $\mathrm{H}_{2} \mathrm{O}_{2}$ appeared to be about $35 \mu \mathrm{M}$ (Fig. 2A), about half the total phenolic degradation of AS plus HAP, 70-75 $\mu \mathrm{M}$. Interestingly, in reactions with HAP alone, the 

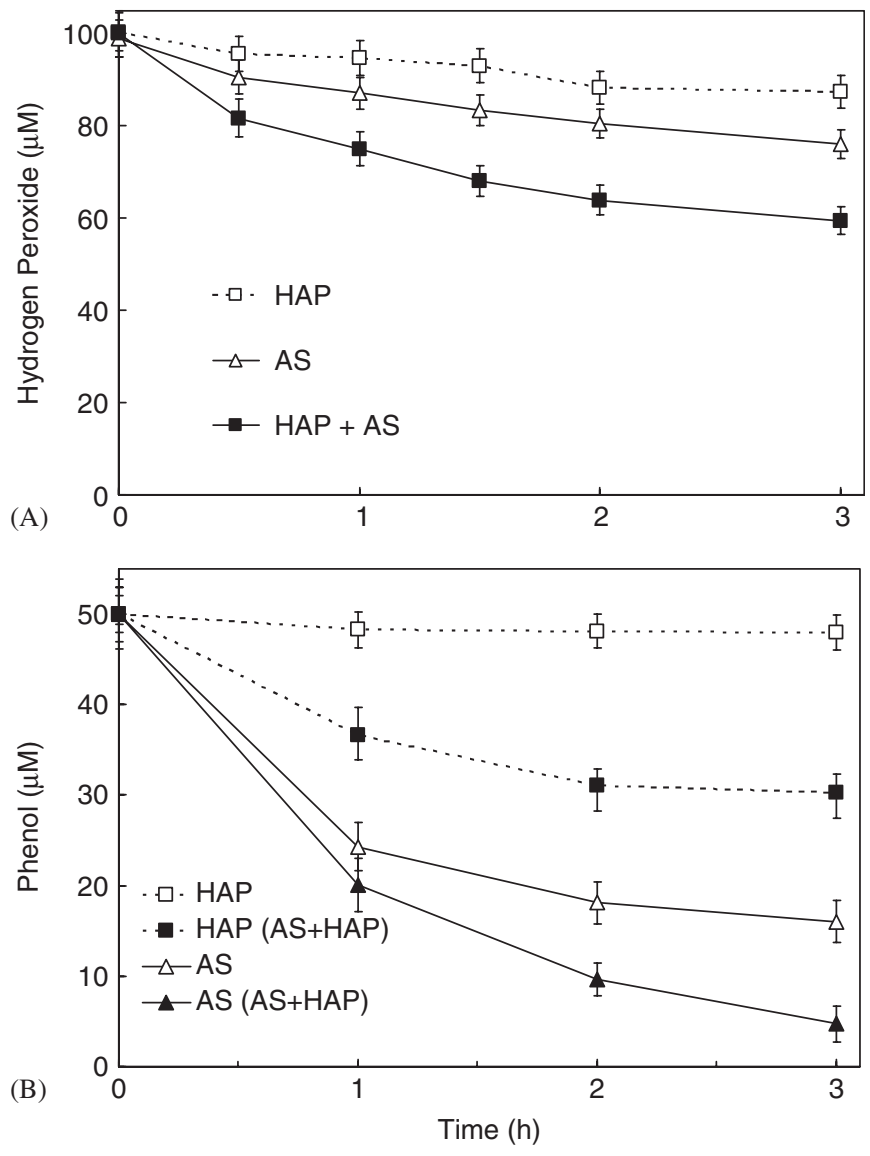

Fig. 2. Monitoring the reaction of AS and/or HAP with horseradish peroxidase and $\mathrm{H}_{2} \mathrm{O}_{2}$. The reaction mixtures contained $0.036 \mathrm{U} \mathrm{mL}^{-1}$ horseradish peroxidase in assay buffer, $\mathrm{pH} 6,100 \mu \mathrm{M} \mathrm{H}_{2} \mathrm{O}_{2}$, and $50 \mu \mathrm{M}$ of either AS or HAP, or $50 \mu \mathrm{M}$ each AS and HAP. (A) Hydrogen peroxide was measured spectrophotometrically using the FOX2 assay which involved oxidation of xylenol orange. (B) The concentration of the phenolics, AS and HAP, was measured by HPLC-UV. See Section 2 for details.

$\mathrm{H}_{2} \mathrm{O}_{2}$ decreased nearly $10 \mu \mathrm{M}$ (Fig. 2A) while the HAP concentration decreased less than $3 \mu \mathrm{M}$.

\subsection{Need for an initial oxidative burst}

The need for an oxidative burst to initiate this reaction was apparent when using tobacco suspension cells. Unlike soybean cells, our tobacco cell suspensions do not produce an oxidative burst upon preparation and transfer to assay buffer. Addition of AS and HAP to tobacco cells did not elicit $\mathrm{H}_{2} \mathrm{O}_{2}$ production or stimulate phenolic degradation (Fig. 3). Previous studies [9] had demonstrated that addition of $\mathrm{HKBac}$ to tobacco suspension cells would produce a brief burst of $\mathrm{H}_{2} \mathrm{O}_{2}$, about $50 \mu \mathrm{M}$ with these suspensions (Fig. 3A). The same general pattern of $\mathrm{H}_{2} \mathrm{O}_{2}$ production and phenolic degradation that was seen in soybean treatments occurred with the HKBac treated tobacco cells (HKbac-tobacco). HKbac-tobacco suspensions treated with $100 \mu \mathrm{M}$ HAP responded similarly to
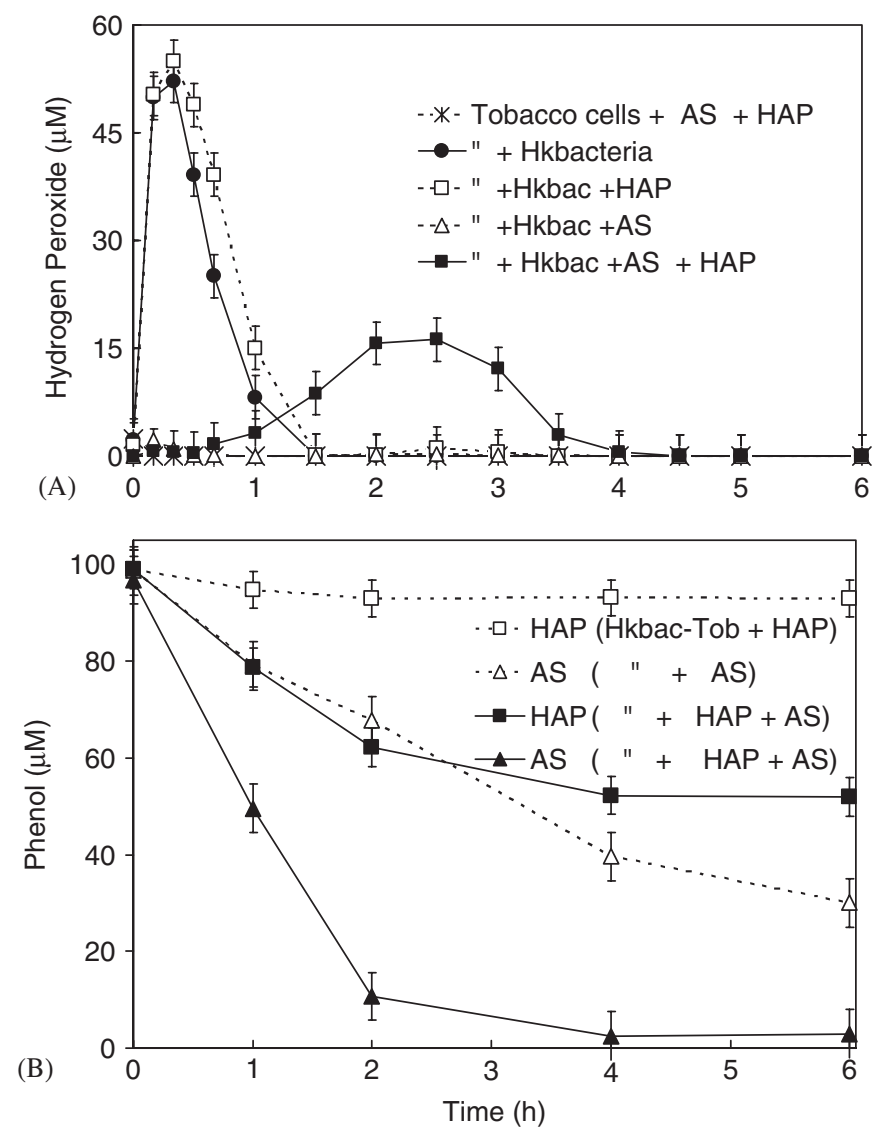

Fig. 3. Monitoring the extracellular $\mathrm{H}_{2} \mathrm{O}_{2}$ levels and phenolic concentrations of suspensions of tobacco cells incubated with AS and HAP after treatment with heat-killed bacteria (HKBac). The tobacco cell suspensions, $0.5 \mathrm{~g} \mathrm{~mL}^{-1}$, were treated with $\mathrm{HKBac}$, equivalent to $10^{-8} \mathrm{cfu}$, and either $100 \mu \mathrm{M}$ AS or HAP, or both AS and HAP. Samples were periodically removed. (A) Hydrogen peroxide was measured spectrophotometrically using the FOX2 assay which involved oxidation of xylenol orange. (B) The concentration of the exogenously added phenolics, AS and HAP, was quantified using HPLC-UV. See Section 2 for details.

untreated tobacco cells, producing an initial burst of $\mathrm{H}_{2} \mathrm{O}_{2}$ (Fig. 3A). HPLC-UV analysis indicated that less than $10 \mu \mathrm{M}$ HAP was degraded over the $6 \mathrm{~h}$ period (Fig. 3B), indicating, as in soybean, that HAP was not an ideal substrate for apoplastic peroxidases to scavenge the $\mathrm{H}_{2} \mathrm{O}_{2}$. HKbac-tobacco suspensions treated with $100 \mu \mathrm{M}$ AS did not accumulate $\mathrm{H}_{2} \mathrm{O}_{2}$ during the $6 \mathrm{~h}$ period (Fig. 3A). Nearly $40 \mu \mathrm{M}$ AS was metabolized during the $6 \mathrm{~h}$ period (Fig. 3B), suggesting that AS can be utilized in tobacco, as well as soybean, to scavenge $\mathrm{H}_{2} \mathrm{O}_{2}$.

As with soybean cells, when HKbac-tobacco cells were treated with both AS and HAP, $100 \mu \mathrm{M}$ each, $\mathrm{H}_{2} \mathrm{O}_{2}$ accumulated reaching $15 \mu \mathrm{M}$ (Fig. 3A), which was less than in soybean (Fig. 1A). The phenolic degradation response of the HKBac-tobacco was similar in magnitude to that of similarly treated soybean cells (Fig. 1B), depleting nearly all of the $100 \mu \mathrm{M}$ AS within $4 \mathrm{~h}$, and reducing the HAP by $50 \mu \mathrm{M}$ (Fig. 3B). 


\subsection{Effect of varying the phenolic concentration}

To gain insight into the relationship between the two phenolics and $\mathrm{H}_{2} \mathrm{O}_{2}$ production, soybean cells were treated with varying concentrations of each phenolic. When soybean cells were treated with a constant amount of HAP, $100 \mu \mathrm{M}$, plus varying amounts of AS, $0-100 \mu \mathrm{M}$, the amount of $\mathrm{H}_{2} \mathrm{O}_{2}$ detected increased with the amount of AS present in the initial treatment (Fig. 4A). The initial rate of $\mathrm{H}_{2} \mathrm{O}_{2}$ accumulation appeared to be the same for the different concentrations of AS. The major effect of the AS concentration was the duration of the $\mathrm{H}_{2} \mathrm{O}_{2}$ accumulation and therefore the magnitude of the $\mathrm{H}_{2} \mathrm{O}_{2}$ accumulation (Fig. 4A). The accumulation of $\mathrm{H}_{2} \mathrm{O}_{2}$ ceased at about the same time the AS concentration was nearly depleted (Fig. 4C), and the HAP degradation decreased (Fig. 4B). For example, the $\mathrm{H}_{2} \mathrm{O}_{2}$ accumulation in cells treated with HAP plus $50 \mu \mathrm{M}$ AS stopped around $2 \mathrm{~h}$ (Fig. 4A), concurrent with the depletion of AS (Fig. 4C) reduced degradation of HAP (Fig. 4B).

When soybean cells were treated with a constant amount of AS, $100 \mu \mathrm{M}$, plus varying amounts of HAP, $0-100 \mu \mathrm{M}$, the amount of $\mathrm{H}_{2} \mathrm{O}_{2}$ detected increased with the HAP concentration in the initial treatment (Fig. 4D). The starting time of $\mathrm{H}_{2} \mathrm{O}_{2}$ accumulation was similar for the different concentrations of HAP; however, the rate of accumulation increased with HAP concentration. The accumulation of $\mathrm{H}_{2} \mathrm{O}_{2}$ appeared to cease when AS was nearly depleted (Fig. 4F) and the HAP degradation decreased (Fig. 4E). For example, in treatments with AS plus $100 \mu \mathrm{M}$ HAP, the $\mathrm{H}_{2} \mathrm{O}_{2}$ accumulation stopped around $3 \mathrm{~h}$ (Fig. 4D), concurrent with the depletion of AS (Fig. 4F) reduced degradation of HAP (Fig. 4E).

\section{Discussion}

This study demonstrated two interesting phenomena related to apoplastic metabolism, (1) the synergistic cooxidation of certain apoplastic phenolics and (2) the subsequent production of ROS in the extracellular environment of suspensions cells. When equal amounts of AS and HAP were added to soybean suspension cells undergoing an oxidative burst, and thus producing $\mathrm{H}_{2} \mathrm{O}_{2}$, the rate and amount of degradation of each phenolic compound was increased (Figs. 1 and 4). When the same phenolics were added to tobacco suspension cells, a similar synergistic co-oxidation accompanied by the production of ROS occurred, but only after the cells were treated with HKBac to elicit an initial oxidative burst (Fig. 3). The synergistic co-oxidation of AS and HAP could be duplicated in vitro, with both horseradish peroxidase (Fig. 2) and soybean peroxidase (data not shown); however, the production of ROS could not be demonstrated. The ROS production by cells treated with these phenolic compounds coincided with a comparable increase in oxygen consumption by the suspension mixture (data not shown).
The mechanism involved in this phenolic co-oxidation would appear to involve peroxidase activity based on the similarity of the synergistic phenolic metabolism that occurred with horseradish peroxidase (Fig. 2B) and the suspension cells (Figs. 1B and 3B). Unlike most biological redox reactions, which require specific cofactors, peroxidases have a wide range of substrates from which they can abstract electrons. The catalytic cycle of peroxidase is shown in Fig. 5a-c. The native enzyme is oxidized by $\mathrm{H}_{2} \mathrm{O}_{2}$ losing two electrons to form Compound-I. Compound I takes an electron from a reducing phenol, producing a phenolic radical and forming the Compound-II. Compound-II repeats the later step forming another phenolic radical reverting back to the native enzyme. These phenolic radicals can have many fates including disproportionation, dimerization, polymerization, or oxidation of other substrates including other phenolics (co-oxidation) or oxygen (Fig. 5).

In order to aid chemical analysis of the exogenous phenolics added to the cell suspensions, relatively high concentrations, $50-100 \mu \mathrm{M}$, were used compared to the endogenous concentrations, $2-6 \mu \mathrm{M}$, detected in previous studies with tobacco cell suspensions [5]. As discussed in the previous study, it seems feasible that the concentration of the phenolics in the cell wall matrix of suspension cells would be much greater than that detected after dilution into the total suspension fluid. In suspensions, the cell volume is about $5 \%$ of the total volume and only a fraction of this cell volume is composed of the cell wall matrix. Therefore, although the total amount of exogenous phenolics metabolized by these cells was probably much greater than they would normally encounter, the concentration of the phenolics seems biologically feasible.

Based on the work described in this study as well as other studies of co-oxidation [6,7,10,11], it would appear that AS would be the preferred substrate to react with peroxidase (Fig. 2). The AS radicals are fairly stable [12] and react with either $\mathrm{AS}^{*}, \mathrm{O}_{2}$, or HAP if present (Fig. 5d-f). The presence of HAP would increase its oxidation by AS, as well as reduce disproportionation of AS (Fig. 5d), which might explain the observed apparent increase in oxidation rate of both phenolics (Figs. 1B, 2B). Consistent with this: (1) the rate of HAP metabolism decreased once the AS was depleted in suspension cell treatments containing both phenolics (Figs. 1-4); (2) the initial rate of HAP metabolism was proportional to the AS concentration (Fig. 4B).

The mechanism of $\mathrm{H}_{2} \mathrm{O}_{2}$ production observed in this study is not clear. It could occur via the reaction of phenolic radicals with oxygen, producing superoxide and subsequently $\mathrm{H}_{2} \mathrm{O}_{2}$ (Fig. 5f, h); however, it is likely that other circumstances are involved since this was only observed in suspension cells. It seems likely that the HAP radical was the major component involved in ROS production, since in the absence of HAP, AS was metabolized but did not produce $\mathrm{H}_{2} \mathrm{O}_{2}$. Also the initial rate of $\mathrm{H}_{2} \mathrm{O}_{2}$ production appears dependent on the HAP 

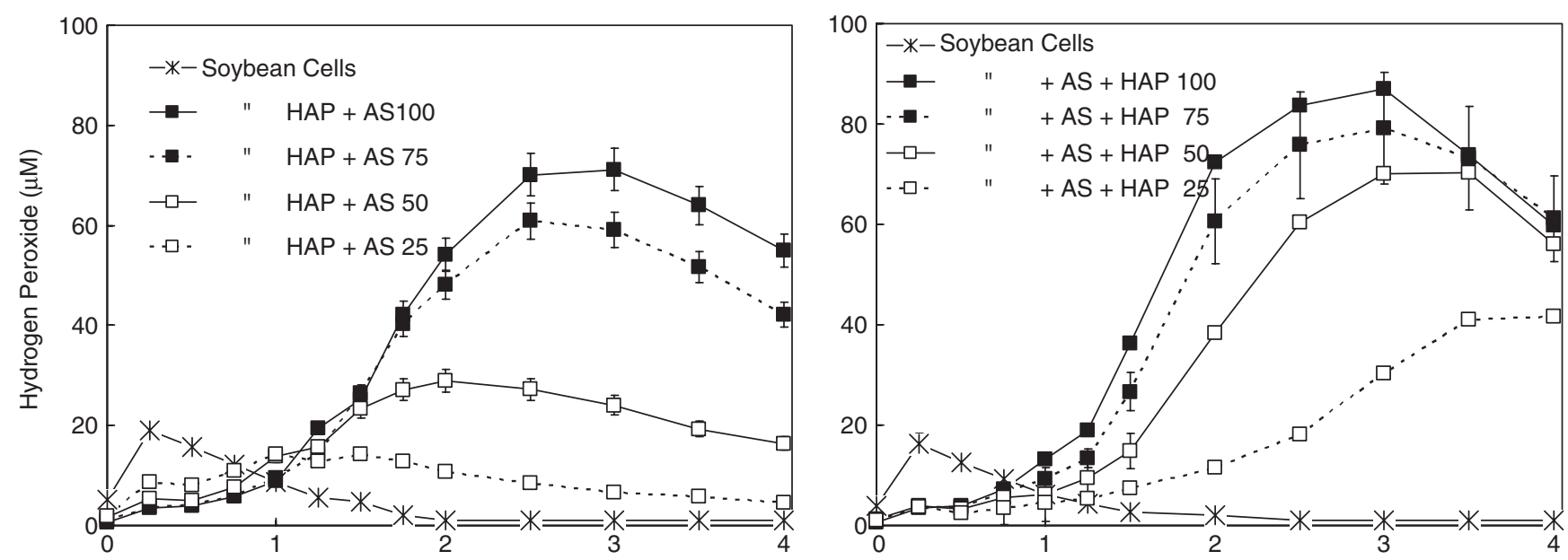

(A)

(D)
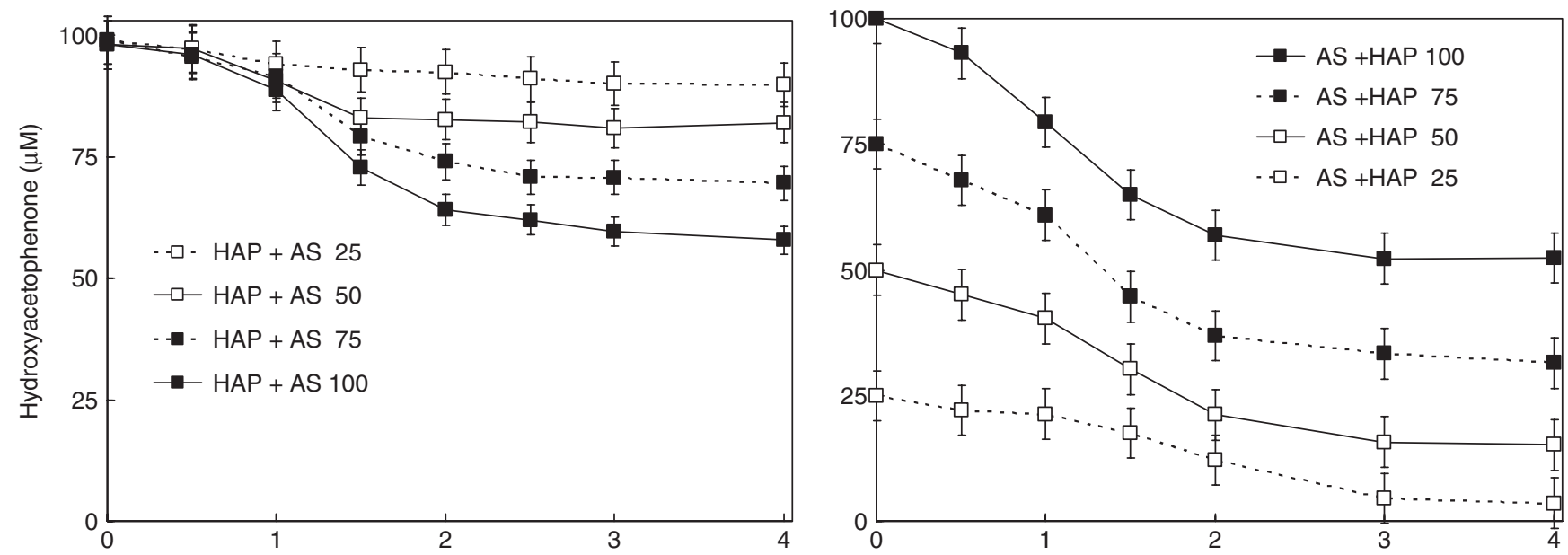

(B)

(E)
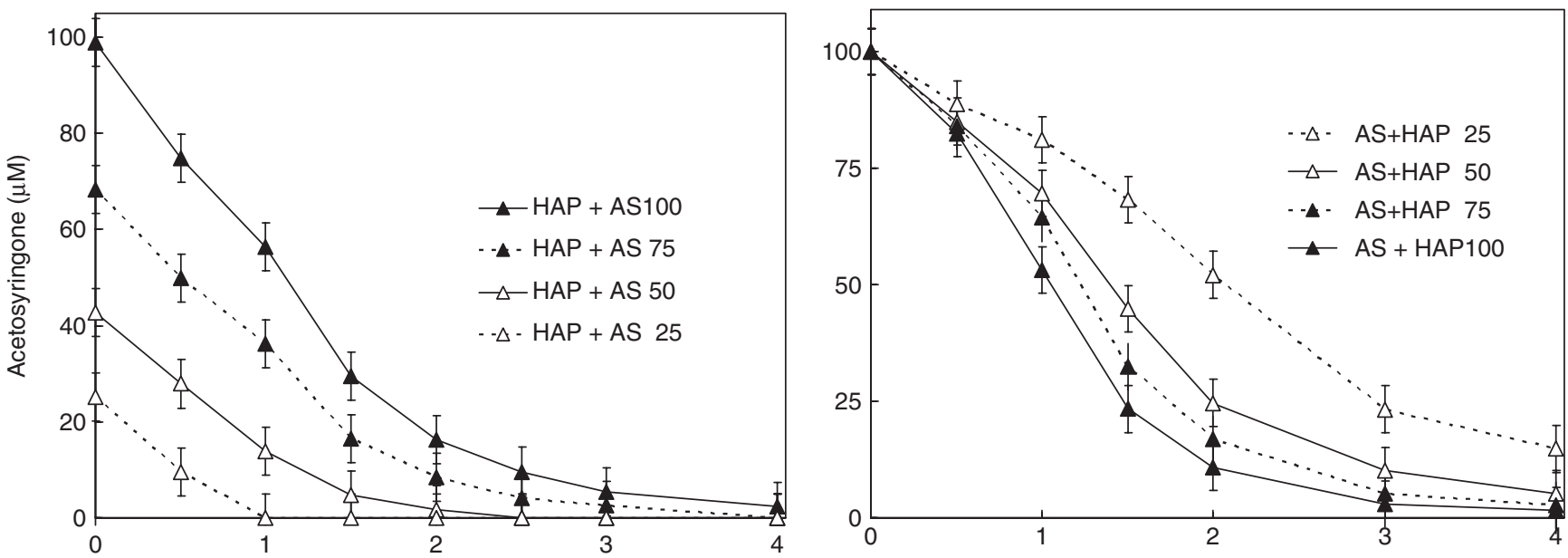

(F)

Fig. 4. Effect of varying the concentration of either AS or HAP in soybean cell suspensions on $\mathrm{H}_{2} \mathrm{O}_{2}$ accumulation and phenolic degradation. (A-C) Soybean cell suspensions, $0.5 \mathrm{~g} \mathrm{~mL}^{-1}$, in assay buffer were treated with exogenous $\mathrm{HAP}, 100 \mu \mathrm{M}$, plus varying concentrations of AS ranging from 0 to $100 \mu \mathrm{M}$ as indicated. (D-F) Soybean cell suspensions were treated with exogenous AS, $100 \mu \mathrm{M}$, plus varying concentrations of HAP ranging from 0 to $100 \mu \mathrm{M}$ as indicated. Hydrogen peroxide concentrations in the supernatant were determined with the FOX2 xylenol orange assay (A, D). The concentrations of HAP (B, E) and AS (C, F) were determined by HPLC-UV. See Section 2 for details. 


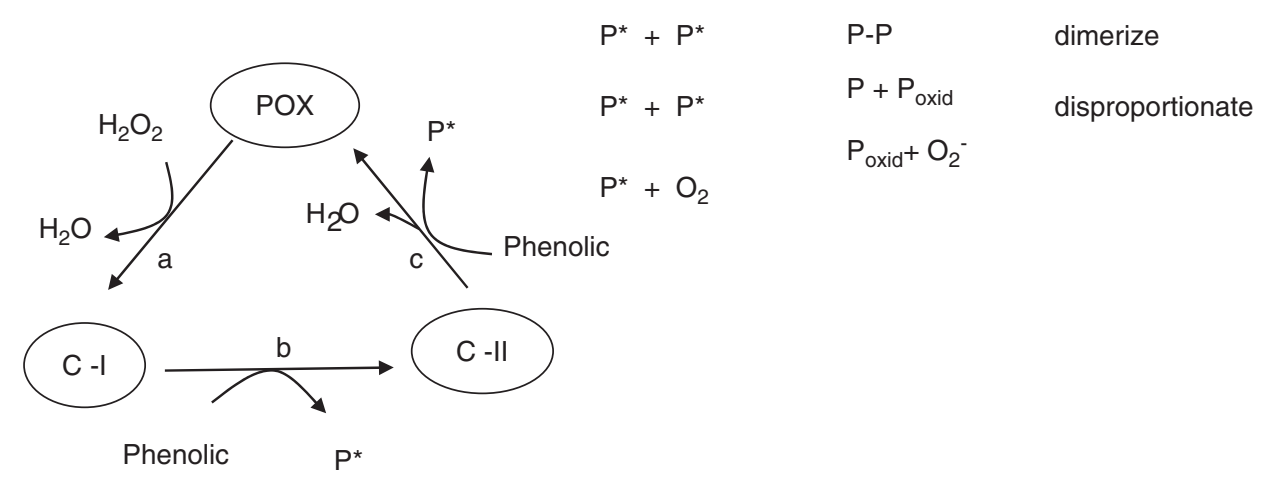

$\begin{array}{llll}\mathrm{d} & \mathrm{AS}^{*}+\mathrm{AS}^{*} & \longrightarrow & \mathrm{AS}_{\text {oxid }}+\mathrm{AS} \\ \mathrm{e} & \mathrm{AS}^{*}+\mathrm{HAP} & \longrightarrow & \mathrm{AS}_{\text {oxid }}+\mathrm{HAP}^{*} \\ \mathrm{f} & \mathrm{HAP}^{*}+\mathrm{O}_{2} & \longrightarrow & \mathrm{HAP}_{\text {oxid }}+\mathrm{O}_{2}^{-} \\ \mathrm{g} & \mathrm{HAP}^{*}+\mathrm{HAP}^{*} \longrightarrow \mathrm{HAP}_{\text {oxid }}+\mathrm{HAP} \\ \mathrm{h} & \mathrm{O}_{2}^{-}+\mathrm{O}_{2}^{-} & \longrightarrow & \mathrm{H}_{2} \mathrm{O}_{2}+\mathrm{O}_{2}\end{array}$

Fig. 5. Traditional peroxidase-related redox mechanisms. (a) The native peroxidase enzyme loses 2 electrons to $\mathrm{H}_{2} \mathrm{O}_{2}$ forming compound-I (C-I). (b) C-I can gain an electron from a phenolic substrate producing compound-II (C-II) and a phenolic radical ( $\left.\mathrm{P}^{*}\right)$. (c) C-II will repeat the later process reverting back to its native state. $\mathrm{P}^{*}$ may dimerize, disproportionate, or donate an electron to $\mathrm{O}_{2}$ forming superoxide $\left(\mathrm{O}_{2}^{-}\right)$. (d) AS radical (AS*) may disproportionate, or (e) oxidize HAP forming a radical (HAP*). (f) $\mathrm{HAP}^{*}$ may combine with $\mathrm{O}_{2}$ forming superoxide, or (g) disproportionate. (h) $\mathrm{O}_{2}^{-}$may form $\mathrm{H}_{2} \mathrm{O}_{2}$ via superoxide dismutase or disproportionation.

concentration (Fig. 4D). Unfortunately, the accumulation of $\mathrm{H}_{2} \mathrm{O}_{2}$ cannot be explained by the stoichiometry of these reactions. One cycle of the peroxidase pathway would consume one molecule of $\mathrm{H}_{2} \mathrm{O}_{2}$ and under the best of conditions produce one molecule of $\mathrm{H}_{2} \mathrm{O}_{2}$, since two phenolic radicals would produce two superoxide radicals and subsequently one $\mathrm{H}_{2} \mathrm{O}_{2}$ (Fig. 5). Additional factors must be involved in the apoplastic $\mathrm{H}_{2} \mathrm{O}_{2}$ production. Other sources of apoplastic ROS production have been nicely summarized by Bolwell and Wojtaszek [13], however, their connection to the current phenomenon is not clear.

The phenomenon of co-oxidation of phenolics has been an area of intense investigation in the pharmaceutical field where two or more phenolic drugs are prescribed and has revealed effects that could just as likely occur in plants $[6,11]$. Peroxidases and other redox-active proteins in animals have been shown to metabolize a number of phenolic compounds in vivo, leading to modifications of their bioactivity, which could be either beneficial or detrimental [10,14-17]. For example, rifampicin, a broadspectrum antibiotic used in tuberculosis therapy, inhibits bacterial RNA polymerase, but also has immunosuppressive properties in humans that are attributed to its oxidation product, rifampicin quinone [10]. The quinone results from the oxidation of rifampicin by ROS at the infection or inflammation site. This oxidative reaction can be increased substantially by co-oxidation with paracetamol, a phenolic painkiller often taken by patients. There is concern that the paracetamol radically reduce the rifampicin concentration to ineffective levels. Another example of phenolic co-oxidation affecting bioactivity involves the interaction of acetaminophen, a common painkiller, and anthracycline drugs used in anticancer therapy [16]. The acetaminophen is a good substrate for endogenous peroxidase when oxidative conditions occur in stressed tissue. The phenolic radical produced will oxidize and degrade the anthracycline drug which normally would not be affected. Because of this finding, the practice of using these drugs together to treat cancer is being reexamined.

We have previously demonstrated the bioactive potential of AS, an apoplastic phenol found in tobacco suspension cells, in plant bacterial interactions [5]. When added exogenously to tobacco or potato cell suspensions treated with bacterial pathogens, AS caused physiological symptoms to occur earlier. In light of the current study, the possibility that the AS might have had a co-oxidative effect on other apoplastic phenolics in these suspension cells thus altering their bioactivity must be considered. Several studies have noted that addition of various phenolic compounds, such as salicylic acid, aromatic monoamines, 
and phenylethylamine, have all been found to induce responses similar to pathogens induced responses [18-21]. Although the ROS production is often the focus of these investigations, the co-oxidative effects of these chemicals on the apoplastic phenolics is often overlooked.

Because the apoplast is one of the first arenas in which the molecular interaction between the plant and pathogen occurs, it is essential to understand the molecular processes that take place. It is a complex environment and due to its separation from the cytoplasm, can undergo rapid transitions and conditions that would not be tolerated in the cytoplasm. Because of the complexity of this environment, it has been very difficult to examine the exact nature of many of the events that occur. The cell suspension system described herein allows minimally invasive sampling and analysis of the extracellular/apoplast fluid providing some insight into the apoplastic chemistry.

\section{Acknowledgment}

This investigation was partially supported by Grant No. 2682 of the International Science and Technology Center.

\section{References}

[1] Brown I, Mansfield J, Trethowan J, Kerry M, Bolwell GP. Localization of components of the oxidative cross-linking of glycoproteins and of callose synthesis in papillae formed during the interaction between non-pathogenic strains of Xanthomonas campestris and French bean mesophyll cells. Plant J 1998;15:333-43.

[2] McLusky SR, Bennett MH, Beale MH, Lewis MJ, Gaskin P, Mansfield JW. Cell wall alterations and localized accumulation of feruloyl-3'-methoxytyramine in onion epidermis at sites of attempted penetration by Botrytis allii are associated with actin polarisation, peroxidase activity and suppression of flavonoid biosynthesis. Plant $\mathbf{J}$ 1999; 17:523-34

[3] Baker CJ, Mock NM, Whitaker BD, Roberts DP, Rice CP, Deahl $\mathrm{KL}$, et al. Induction of redox sensitive extracellular phenolics during plant-bacterial interactions. Physiol Mol Plant Pathol 2005;66:90-8.

[4] Baker CJ, O'Neill NR, Deahl K, Lydon J. Continuous production of extracellular antioxidants in suspension cells attenuates the oxidative burst detected in plant microbe interactions. Plant Physiol Biochem 2002;40:641-4.

[5] Baker CJ, Mock NM, Whitaker BD, Roberts DP, Rice CP, Deahl $\mathrm{KL}$, et al. Involvement of acetosyringone in plant-pathogen recognition. Biochem Biophys Res Comm 2005;328:130-6.

[6] Goodwin DC, Grover TA, Aust SD. Roles of efficient substrates in enhancement of peroxidase-catalyzed oxidations. Biochemistry 1997; 36:139-47.
[7] Hu J, Kulkarni AP. Metabolic fate of chemical mixtures. I. "Shuttle oxidant" effect of lipoxygenase-generated radical of chlorpromazine and related phenothiazines on the oxidation of benzidine and other xenobiotics. Teratog Carcinog Mutagen 2000;20:195-208.

[8] Wolff SP. Ferrous ion oxidation in presence of ferric ion indicator xylenol orange for measurement of hydroperoxides. Meth Enzymol 1994;233:182-9.

[9] Baker CJ, Orlandi EW, Deahl KL. Oxygen metabolism in plant/bacteria interactions: characterization of the oxygen uptake response of plant suspension cells. Physiol Mol Plant Pathol 2000;57: 159-67.

[10] Dos Santos FDJN, Ximenes VF, Da Fonseca LM, Brunetti IL, De Faria Oliveira OMM. Horseradish peroxidase-catalyzed oxidation of rifampicin: Reaction rate enhancement by co-oxidation with antiinflammatory drugs. Biol Pharm Bull 2005;28:1822-6.

[11] Reed GA. Co-oxidation of xenobiotics: lipid peroxyl derivatives as mediators of metabolism. Chem Phys Lipids 1987;44:127-48.

[12] Steelink C. Stable phenoxy radicals derived from phenols related to lignin. J Am Chem Soc 1965;87:2056-7.

[13] Bolwell G, Wojtaszek P. Mechanisms for the generation of reactive oxygen species in plant defence - a broad perspective. Physiol Mol Plant Pathol 1997;51:347-66.

[14] Arlt V, Phillips D, Glatt H, Muckel E, Pabel U, Sorg B, et al. Activation of 3-nitrobenzanthrone and its metabolites by human acetyltransferases, sulfotransferases and cytochrome P450 expressed in Chinese hamster V79 cells. Int J Cancer 2003;105: 583-92.

[15] Dai J, Sloat AL, Wright MW, Manderville RA. Role of phenoxyl radicals in DNA adduction by chlorophenol xenobiotics following peroxidase activation. Chem Res Toxicol 2005;18:771-9.

[16] Reszka KJ, Britigan LH, Britigan BE, Rasmussen GT, Wagner BA, Burns CP, et al. Acetaminophen stimulates the peroxidative metabolism of anthracyclines. Arch Biochem Biophys 2004;427: $16-29$.

[17] Smith KS, Smith PL, Heady TN, Harman WD, Macdonald TL, Trugman JM. In vitro metabolism of tolcapone to reactive intermediates: relevance to tolcapone liver toxicity. Chem Res Toxicol 2003;16:123-8.

[18] Kawano T. Roles of the reactive oxygen species-generating peroxidase reactions in plant defense and growth induction. Plant Cell Rep 2003;21:829-37.

[19] Kawano T, Pinontoan R, Uozumi N, Miyake C, Asada K, Kolattukudy PE, et al. Aromatic monoamine-induced immediate oxidative burst leading to an increase in cytosolic $\mathrm{Ca} 2+$ concentration in tobacco suspension culture. Plant Cell Physiol 2000;41(11): $1251-8$.

[20] Kawano T, Pinontoan R, Uozumi N, Morimitsu Y, Miyake C, Asada $\mathrm{K}$, et al. Phenylethylamine-induced generation of reactive oxygen species and ascorbate free radicals in tobacco suspension culture: Mechanism for oxidative burst mediating $\mathrm{Ca} 2+$ influx. Plant Cell Physiol 2000;41(11):1259-66.

[21] Tenhaken R, Rnbel C. Salicylic acid is needed in hypersensitive cell death in soybean but does not act as a catalase inhibitor. Plant Physiol 1997;115:291-8. 